\title{
NEW SPECIES OF NEMOCERA FROIM PUERTO RICO
}

\author{
By O. A. Johannsen, \\ Cornell University, Department of Entomology.
}

During the months of February and March 1935, Dr. J. G. Needham of Ithaca, New York, in eompany with Dr. Julio García-Díaz of Río Piedras, P. R., collected numerous insects on the island of Puerto Rico, a collection which was considerably augmented later in the season by Dr. García Díaz working alone. Of the Diptera obtained several of the nemocerous families were placed in my hands for identification. Owing to the fact that it was necessary to collect the specimens in aleohol several of the Psychodidae could not be identified. This was true also of some species of other families where represented by females or defective specimens alone. A list of the more striking captures as well as descriptions of previously undescribed species are given herewith.

\section{Chironomidae}

\section{Pentaneura marmorata n. sp.}

․ Head and antennae pale yellow, apical antennal segment, the elongate paIpi and mouthparts infuscated. Twelfth segment of antemna three times as long as the eleventh segment. Thorax and scutellum pale yellow, mesonotum with four broad brown vittae; lateral margins of metanotum and of pronotum brown; pectus largely brown; pleura with about ten irregular brown spots of varying sizes. Abdomen pale yellow, tergites 3,4 and 5 each with a large rectangular brown spot. Legs yellowish white; extreme bases of coxae, a spot on trochanter, a preapical ring on each femur, a ring near base of each tibia and the extreme tips of the tibiae and of the metatarsi, brown. Fore basitarsus seant 0.6 times as long as the tibia, pulvilli absent. Wing marmorated with brown spots as follows: an irregular rectangular spot covering humeral crossrein and arculus; an irregular triangular spot covering the $r-m$ crossrein, extending to the costa; a large brown rectangular area extending from the tip of $R_{1}$ to apex of wing covering the costa and the media, this area with a small hyaline spot along the costa between $R_{1}$ and $R_{2}$; a large irregularly 4branched hyaline spot between radius and media, and another less distinctly margined irregular hyaline spot near apex of the wing; in the basal half of cell $R_{5}$ and just beyond the $r-m$ erossvein with three small dark brown oval spots of which the more distad is the smallest; m-cu crossvein covered in part by a small spot, distad of which in cell $\mathrm{M}$ are about four more or less square spots, the apical one containing a vaguely margined hyaline spot; Cell $\mathrm{C}_{1}$ with two minute basal spots, a square spot filling the space above apex of $\mathrm{Cu}_{2}$ and the cell apically brown margined; behind the cubitus there are about three 
small spots basally, a large square spot under the base of $\mathrm{Cu}_{2}$ and distally filling the margin under the apex of $\mathrm{Cu}_{2}$ an irregular brown area containing an indistinctly margined hyaline spot. The larger wing spots are more or less contiguous with one another. Squamae fringed. Halteres white. Length 2.5 $\mathrm{mm}$, wing $2.4 \mathrm{~mm}$.

Type from Río Cidra, Puerto Rico, March 23, 1925. In the Cornell University Collection.

Pentaneura monilis L., var. peleensis Walley.

Taken at light, Tortuguero Lake, August 15, 1935.

Coelotanypus insulanus n. sp.

\%. Head and antennae yellow, apical antennal segment brownish; eyes slightly emarginate, separated at vertex by a width equal to the distance between the bases of the antennae; thorax including scutellum reddish brown; pleura yellow, metanotum dark brown; mesonotum without acrostichals, the pimple on dise, small. Abdomen yellow, tergites 2 to 7 with basal half or twothirds, brown, eighth tergite and sternite more or less brown. Femora yellowish, apical sixth dark; tibiae yellow, bases of fore and hind pairs and apices of all of them brown; fore tarsi broken off, the apices of the first and second segments of middle and hind tarsi yellow, their apices and the whole of the remaining segments dark brown. Fore tibiae with one, middle and hind tibiae with two spurs. Wings hyaline, veins yellow, $r-m$ erossvein dark brown; petiole of cubitus about half as long as the m-cu crossvein; anterior branch of the cubitus slightly undulate. Squama fringed. Halteres yellow. Length (in alcohol) $2.2 \mathrm{~mm}$.

Yúnez River, Puerto Rico, August 11, 1935. Type in the Cornell University Collection.

\section{Coelotanypus concinnus Coquillett.}

Taken at light. Cartagena Lagoon, August 9.

\section{Cardiocladius obscurus Johannsen}

Taken at light, Cartagena Lagoon, August 9.

\section{Cricotopus aberrans n. sp.}

\%. Head yellow, oceiput, antennae and wiouth parts slightly darker. Eyes pilose, widely separated on the front. Antennae with six segments of which the last is three times as long as the fifth. Thorax yellow, with the three broad vittae on mesonotum, the scutellum and metanotum, brown. Abdomen yellow, the apical half of the second tergite the whole of the third, and the sixth, seventh, eighth and ninth tergites except narrow bases, brown. The terminalia, which are white, resemble those figured for Orthocladius absurdus (N. Y. State Museum, Bull. 86, Plate 33, 7) with about five strong bristles at apex of each 
lobe. Femora whitish with apical third dark brown; fore tibiae white, apical third dark brown, the other tibiae yellow, extreme base of second pair and basal third of hind pair more or less brownish; fore tarsi wholly dark brown, middle and hind tarsi infuscated toward the tip; pulvilli lacking; empodium long; fore basitarsus 0.6 times as long as the tibia. Wing hyaline, veins yellowish, costa produced, cubitus forks distad of the crossvein. Squama not fringed. Halteres white. Length $1.8 \mathrm{~mm}$.

Type from Tanamá River, Puerto Rico, March 12, 1935.

Paratypes from the same locality March 12, 13 and May 11; from Yúnez River, Feb. 27, and Cagüitas River, March 3, 1935. Type in the Cornell University collection.

The color of the middle and hind tibiae in the paratypes shows some variation.

The Orthocladius absurdus Joh. noted above will fall in Cricotopus as defined by Edwards in 1929. Cricotopus insolitus Curran also from Puerto Rico has a similarly constructed terminalia but they are here relatively more slender and elongate than in $C$. aberrans and absurdus.

\section{Cricotopus conformis Curran.}

Taken at light, Yúnez River, Febraury, June; Tanamá River, March, July; Río Cidra, March; Lares, March; Quebrada Joba, March, 1935.

\section{Cricotopus insolitus Curran.}

Taken at light, Río Cidra, June; Yúnez River, February, June, August; Luquillo Mts., June; Tanamá River, March, 1935.

\section{Corynoneura (Thienemaniella) simitis Malloch.}

Taken at light, Yúnez River, June, August; Río Cidra, March, 1935.

\section{Pseudochironomus fulviventris Johannsen}

Taken at light, Yúnez River, June 22; Luquillo Mts., June 10, 1935.

\section{Chironomus (Stenochironomus) furcata n. sp.}

$\hat{\delta}$. Head and antennae yellow, the scape, palpi and proboscis pale brownish. Eyes separated on the front by a width greater than the width of the dorsal process of the eye. Last antennal segment 1.5 times as long as segments 2 to 13 combined. Palpi nearly as long as the last antennal segment, its second and third segments subequal, fourth segment 1.5 times as long as the third. Thorax yellow, the two broad lateral vittae of the mesonotum, base of scutellum, metanotum except for fine median yellow line, three large angular spots on the pleura, and two large spots on the pectus, brown. Thorax produced 
over the head and pronotum reduced as in Stenochironomus. Abdomen yellow, the larger part of the first and the apical third or half of third to sixth, and larger part of the remaining tergites brown. Spur of the ninth tergite long and slender the tip extending caudad to tips of the inferior and superior appendages, the latter slightly enlarged apically with strong anteriorly directly bristles and one long posteriorly directly bristle; the superior appendage enlarged and bristly at base, s!ender, bare and curved apically. Dististyles bristly, longer than the basistyles, gradually widened apically, ending in a fork the inner limb of which is stout, blunt, and thumb-like, the outer limb longer more slender and tapering to a point on which a long slender bristle is placed. Legs yeliow, fore tarsi not bearded, fore basitarsus 1.2 times as long as the tibia; pulvilli well dereloped; fore tibiae with rounded scale; middle and hind tibiae each with two strong spurs on normal combs. Wings hyaline with pale veins including crossvein; the radius ends as far in front of the apex of the wing as the media does behind it; cubitus forks distinctly distad of the crossvein. Squama with a fringe of several hairs. Length $3.5 \mathrm{~mm}$.

Taken at light June 7, 1935. Type and paratypes from Luquillo Mts., Puerto Rico. The lack of wing bars combined with the peculiar furcate distictylesc distinguish this species from other members of the subgenus Stenochironomus. Type and paratypes, Luquillo Mts., June 7, 1935. Type in the Cornel] University Collection.

\section{Chironomus bulbosa Garry.}

This species was originally described from Cuba. Guánica Lagoon, February 24; Yúnez River, June 19; Cartagena Lagoon, August 3 and 10; Tortuguero Lake, August 15.

\section{Tanytarsus (Rheotanytarsus) meridionalis n. sp.}

ô. Pale yellow, including legs, the metanotum and the three vittae of the mesonotum darker yellow. It is probable that in life the abdomen, at least, is somewhat greenish. Eyes separated on the vertex by a distance subequal to the width of the dorsal extension of the eye. Antennal segments 2 to 13 combined about 1.75 times as long as segment 14. Hypopygium closely resembling that figured in New York State Museum Bulletin No. 86, plate 33, 4; the apical fifth of dististyles curved down, about a fourth as wide as the dististyles near the middle; dorsal spur of ninth tergite acute, ending a little distad of apex of basistyle; inferior appendages slightly clavate ending beyond tip of the spur, with the usual strong eurved bristles; superior appendages shorter, ending little if any distad of apex of basistyle, apical and distinctly broader than toward the base with a few fine erect bristles; brush slightly shorter than superior appendages, with apical half or two-thirds with flattened blade-like hairs which are broadest at the tip. Anterior tibia with a short sharp spur, fore basitarsus about 2.3 times tibia in length; middle and hind tibiae each with two combs which are separated from each other at the base by a distance nearly half the depth of the comb; each comb with a long, sharp, slightly 
curved spur; pulvilli vestigial; empodium small. Wings hyaline with pale reins; rather densely hairy; posterior branch of radius ends but very slightly distad of anterior branch of the cubitus; media ends in the tip of the wing; cubitus forks far distad of the short eross vein. Length $1.70 \mathrm{~mm}$, wing $1.25 \mathrm{~mm}$.

q. In coloring like the male. Antennae seven segmented, the second and third more or less fused, the intermediate segments spindle-shape, without distinct necks, the last segment slender, scarcely twice as long as the next to the last. Ratio of fore tibia to basitarsus as in the male. Wing slightly broader than in the male. Length $1.25 \mathrm{~mm}$. Wing length $1.25 \mathrm{~mm}$.

This species differs from the North American T. exiguus Joh. and from the South American T. abbreviatus Kieff, in the relatively longer fore basitarsus and the relatively shorter terminal antennal segment in the male.

Type and paratypes from Yúnez River, August 14, 1935. Other localities: Río Cidra, March 23; Luquillo Mts., June 10; Tanamá River, March 12; Quebrada Jobo, March 7; Tortuguero, March 19, 1935. Type and paratypes in the Cornell University Collection.

\section{Ceratopogon (Brachypogon) impar n. sp. (Ceratopogonidae)}

\%. Thorax including scutellum and metanotum black, slightly cinereous, notum sparsely short bristled; abdomen yellow, third and fourth tergites each with a pale brown median transverse band interrupted and darker in the middle; fifth and sixth tergites show a trace of an interrupted band in the form of two dark spots place side by side; apex dark; venter yellow. Antennae yellow, seape dark. Legs yellow, basal half of fore and middle femora and extreme apex of all of these, dark; claws equal. Wings milky, without microtrichia; apex of radial veins fused into a conspicuous dark stigma ending about the middle of the wing but slightly distad of the level of apex of $\mathrm{Cu}_{2} ;$ media ends slightly behind apex of wing. Halteres pale. Length 0.8 $\mathrm{mm}$ in alcohol; wing $0.7 \mathrm{~mm}$.

The coloring of the abdomen and legs seems to be subject to some variation since in the paratype the paired marks on the abdomen are fused on the middle line and the middle and hind tibiae are slightly darkened in the middle section.

This species differs from the European C. vitiosus in coloring and in the relatively shorter radial veins. Type from El Yunque trail, June 10, 1935; paratype from Luquillo Mts., June 7, 1935. In the Cornell University Collection.

\section{Paltostoma agyrocincta Curran (Blepharoceridae).}

Sabana River, March 7; Luquillo Mts., June 7; La Mina Recreation Area, July 14; El Yunque Trail, July 27. 


\title{
Key to North American species of Maruina (Psychodidae)
}

\author{
(Based largely on descriptions)
}

1. Basal sections of $R_{3}$ and $M_{2}$ obliterated and lacking hairs; wing narrow lanceolate, about four times as long as wide; $R_{5}$ originates distad of the level of the base of $\mathrm{M}_{3}$; hairs of body and wings brown, hair tufts on thorax and wing base blackish brown. Puerto Rico_-_-_hirta n. sp.

Basal sections of: $R_{3}$ and $M_{2}$ distinct, or differing in other characters

2. Thorax with black or brown hairs; antennae three-fourths as long as width of wing; legs black, basitarsi white; ventral plate elongate, narrowed toward the base. Length of female $2 \mathrm{~mm}$. California and Washington_-_-_-_-_-_-_-_-_-_-_-_anceolata Kinkaid

Thorax largely with yellow hairs

3. Legs uniformly blackish brown; wing. with blackish hair, basal part to the fold with whitish hair. Male. Maryland_-____________nuda Dyar

Legs more or less pale

4. Antennae nearly as long as the body, segments beyond the second over three times as long as broad; petiole of $R_{3}+{ }_{4}$ less than half as long as the cell $R_{3}$; petiole of $M_{1}+{ }_{2}$ less than a fourth as long as the cell $\mathrm{M}_{1}$; body and legs covered with yellow hairs; length $1 \mathrm{~mm}$. Female. Mexico cirrata Coq.

Antennae shorter; wing with white tuft at tip

5. Hair of abdomen pale, slightly mixed with blackish; wing uniformly eovered with black hair; length 1 to $1.25 \mathrm{~mm}$. Female. St. Vincent Island angustipennis Will.

Hair of abdomen darker, elothed with short black and white, and longer dark hair; tip of ventral plate narrow with shallow emargination and rounded lobes; wing with two transverse black bands; length of wing $2.5 \mathrm{~mm}$, breadth $0.45 \mathrm{~mm}$. Arizona_-_-___-_-_-_unipunctata Haseman

Maruina californiensis Kellogg cannot be included here since only the immature stages are known. The species californica Kinkaid does not belong to the genus Maruina; M. cirrata is placed in the genus on the authority of Dr. Dyar.

\section{Maruina hirta n. sp.}

$\hat{o}$. Hairs on head, body and wings coarse, flattened, scale-like. Hairs on head brown with blackish-brown tufts on each side above the eyes; slender hairs on first basal and on the seven apical antennal segments pale brown, the remaining antennal segments shaggy with somewhat broader, closely erowded blackish-brown hairs. Antennae $0.6 \mathrm{~mm}$ long, the segments short ovate, without distinct necks. Eyes separated on the vertex by nearly three times the width of the eye-bridge. Ground color of thorax and abdomen pale; a dense tuft of blackish hairs anteriorly on mesonotum on each side, remainder of thorax, abdomen and legs more sparsely covered with brown hair. Tarsi pale, sparsely short haired, apical segment dark. Each rving with a dense tuft of long, blackishbrown scale-like hairs on the costa proximad of the fold and another tuft of the same size just distad of the fold, wing reins with long brown hairs, costal and hind 
margin with a dense fringe of long brown hairs, that on the hind margin measuring 0.6 to $0.7 \mathrm{~mm}$ in length. The wing membrane as seen in the denuded wing is tinted pale brownish with a hyaline patch distad of the middle and more or less hyaline basally, in cells $R_{5}, M_{1}+_{2}$ and the anal angle. The venation somewhat resembles that figured by Haseman (1907) for M. unipunctata Has. but the bases of $R_{3}$ and $\mathrm{M}_{2}$ are obliterated. It resembles still more closely that figured by Müller for $M$. pilosella Müller (1895) differing in that $R_{2}$ is about as long as the petiole of $R_{4}$ and $R_{5}$, and also that the interruption at the bases of $R_{3}$ and $M_{2}$ is more extensive. Wing about four times as long as wide, apex acute as in $M$. unipunctata. The halteres are pale.

The hypopygium is of the usual Psychodid type; minor appendages hairloss, well developed, the basal segment more or less cylindrical, more than twice as long as wide, the apical segment a little shorter, but more slender and tapering to the apex. Basal segment of major appendages pear-shaped, basally with twenty or more long, slender, erect hairs; apical segment about .035 long, capitate, the head-end with small dark scales, the petiole much attenuated and bare. Last sternite (dorsal in position) slightly longer than broad, parallel sided, apex truncate with rounded angles. Ninth tergite (ventral in position) slightly broader than long with median somewhat truncated lobe between the short, rounded lateral lobes. Length of insect $1.6 \mathrm{~mm}$; wing lenth $1.3 \mathrm{~mm}$.

․ Like the male except for sex characters. The palpi are $0.3 \mathrm{~mm}$ long, the apical segment $0.125 \mathrm{~mm}$. The shaggy tuft of densely placed hairs on the basal antennal segments so conspicuous in the male is lacking.

The holotype from the Guaynabo River, Puerto Rico, February 21, 1935; allotype and paratype from the Yúnez River, June 20, 1935.

Larvae and pupae collected at the same time and place resemble those of Maruina californiensis Kellog (1901). In the Cornell University Collection. 